\title{
Freedom of Religion under Bills of Rights
}

\author{
Edited by \\ Paul Babie and Neville Rochow
}

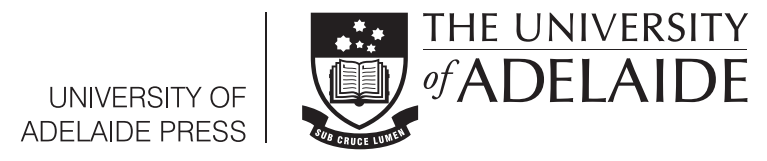


Published in Adelaide by

University of Adelaide Press

Barr Smith Library

The University of Adelaide

South Australia

5005

press@adelaide.edu.au

www.adelaide.edu.au/press

The University of Adelaide Press publishes externally refereed scholarly books by staff of the University of Adelaide. It aims to maximise the accessibility to its best research by publishing works through the internet as free downloads and as high quality printed volumes on demand.

Electronic Index: this book is available from the website as a down-loadable PDF with fully searchable text. Please use the electronic version to serve as the index.

(C) 2012 The Authors

This book is copyright. Apart from any fair dealing for the purposes of private study, research, criticism or review as permitted under the Copyright Act, no part may be reproduced, stored in a retrieval system, or transmitted, in any form or by any means, electronic, mechanical, photocopying, recording or otherwise without the prior written permission. Address all inquiries to the Director at the above address.

For the full Cataloguing-in-Publication data please contact National Library of Australia

ISBN (electronic) 978-0-9871718-1-8

ISBN (paperback) 978-0-9871718-0-1

Book design: Midland Typesetters

Cover design: Emma Spoehr, John Emerson, Paul Babie

Paperback printed by Griffin Press, South Australia 


\section{Contents}

Acknowledgments

vii

List of Contributors

ix

Foreword by The Hon Sir Anthony Mason AC KBE: Human Rights and

Courts

\section{INTRODUCTION}

1 Protecting Religious Freedom under Bills of Rights: Australia as Microcosm

Paul Babie and Neville Rochow

\section{SETTING THE SCENE}

2 How Religion Constrains Law and the Idea of Choice Ngaire Naffine

3 Is the Emperor Wearing the Wrong Clothes? Human Rights and Social Good in the Context of Australian Secularity: Theological Perspectives Bruce Kaye

4 Anniversary Overlap: Or What happens when St Paul Meets the Universal Declaration of Human Rights Alan Cadwallader

\section{CONTEMPORARY FREEDOM OF RELIGION ISSUES}

5 Defamation and Vilification: Rights to Reputation, Free Speech and Freedom of Religion at Common Law and under Human Rights Laws Neil Foster

6 Should an Australian Bill of Rights Address Emerging International Human Rights Norms? The Challenge of 'Defamation of Religion' Robert C Blitt

7 Christian Concerns about an Australian Charter of Rights Patrick Parkinson

8 Apostasy in Islam and the Freedom of Religion in International Law Asmi Wood 


\section{COMPARATIVE EXPERIENCE WITH FREEDOM OF RELIGION}

\section{Europe}

9 Political Culture and Freedom of Conscience: A Case Study of Austria

David M Kirkham

10 The Sky is Falling if Judges Decide Religious Controversies! -

Or is it? The German Experience of Religious Freedom Under a Bill of Rights Cornelia Koch

11 Religious Freedom in a Secular Society: The Case of the Islamic Headscarf in France

Nicky Jones

12 Religious Freedom in the UK after the Human Rights Act 1998

Ian Leigh

\section{North America}

13 Judicial Interpretation, Neutrality and the US Bill of Rights Frank S Ravitch

14 Protecting Religious Freedom: Two Counterintuitive Dialectics in

US Free Exercise Jurisprudence

Brett $G$ Scharffs

15 Walking the Tightrope: The Struggle of Canadian Courts to Define Freedom of Religion under the Canadian Charter of Rights and Freedoms Barbara Billingsley

16 Quo Vadis The Free Exercise of Religion? The Diminishment of Student Religious Expression in US Public Schools

Charles J Russo

\section{Australia and New Zealand}

17 Freedom from Discrimination on the Basis of Religion

Kris Hanna

18 Ruminations from the Shaky Isles on Religious Freedom in the Bill of

Rights Era

Rex Tauati Ahdar

19 Indigenous Peoples and Bills of Rights

Paul Rishworth 


\title{
4
}

\section{Anniversary Overlap: Or What Happens When St Paul Meets the Universal Declaration of Human Rights}

\author{
Alan Cadwallader
}

In 2007, Paul Gray, a columnist for the Melbourne Herald Sun, vented his spleen against the Australian Catholic Film Office and the Australian Film Institute for the awards given to Rolf de Heer's film Ten Canoes. ${ }^{1}$ His reason: the film's subtitles. Australian money, he argued, was fritted away on a film that was not in the 'national language'. He went on to claim that this made the film 'elitist', 'baffling', 'highminded', its awards being a case of 'the unsociable rushing to laud the unwatchable'. The Jesuit Father Richard Leonard's rationale for the ACFO award was that it 'can only be a useful instrument for reconciliation'. In contrast, Gray queried whether any reconciliation was possible. For him, reconciliation was tied to the universality of English at least as defined with an Australian frame of reference, or even broader, movies as 'the business of the masses'. Drew Roberts, from the Adult Multicultural Education Services in Melbourne, underscored the significance of Australia's first Indigenous language (Ganalbingu) film in a context where only 18 of 128 extant Indigenous languages are currently exempt from the threat of extinction. ${ }^{2}$ Death and loss have already severely decimated the 500 dialects and 250 languages estimated to have layered the great southern land before white settlement. Gray at least acknowledged that he was a 'white guy' but what he did not acknowledge was that white guys who speak English are presumably the measure of universality. The loss

'Paddling a new canoe', Herald Sun (Sydney), 8 Jan 2007.

ABC Radio National, 'Lingua Franca', Lingua franca, 1 August 2009. 
of bilingual education in the Northern Territory is but one structural parallel to this attitude. $^{3}$

This concrete example highlights one of the ongoing conflicts over human rights: that between the universal and the particular. It plays out in issues of identity framed within ethnicity, culture, gender, sexual orientation and a host of other parameters where the particular is frequently sacrificed to the universal, even though the universal is itself tainted as particularly Western and Judeo-Christian. ${ }^{4}$ In this sense, given that the universal, in Gray's terms, is tied to the linkage of art with business so that worth is defined in terms of the box office, "human rights" is nothing other than the ideology of modern liberal capitalism'. At least, this is the assessment of the French Marxist philosopher, Alain Badiou. ${ }^{5}$

\section{Badiou's revised quest for the universal}

Badiou does not want to jettison universality. Rather, he wants to re-position universality in an ethics of truth not in morality. Rights defined by morality, he finds, are always undermined by an often Western capitalist particular determination masquerading as the universal when it is in fact replete with obscurantism, commercial academicism, the politics of profit and inequality and sexual barbarism. ${ }^{6}$ Truth is reduced to a linguistic form, an instrument in the exercise of power. For Badiou, the universal has nothing to do with either dominator or victim. ${ }^{7}$ These are the frequent indicators that competition and/or moral relativism is alive and well, even over the 'universality' of rights.

To assist Badiou in the construction of a universalism that is built on truth rather than competition, he turns, like all good recent Marxists, ${ }^{8}$ to the apostle, St Paul. Badiou is not interested in any metaphysical or theological reading of Paul's letters — he remains

3 See J Simpson, J Caffrey and P McConvell, 'Gaps in Australia’s Indigenous Language Policy: Dismantling bilingual education in the Northern Territory'(2009) AIATSIS Research Discussion Paper 24.

4 See C R Fontaine, With Eyes of Flesh: The Bible, Gender and Human Rights (2008) 11.

5 See J Barker, Alain Badiou: A critical introduction (2002) 135.

6 Alain Badiou, Christoph Cox, et al, On Evil: An Interview with Alain Badiou (2002) Cabinet Magazine Online <http://www.cabinetmagazine.org/issues/5/alainbadiou.php> at 9 September 2011..

7 A Badiou, Saint Paul: The Foundation of Universalism (R Brassier trans) (2003), 6.

8 Cf S Žižek, The Ticklish Subject: The Absent Centre of Political Ontology (1999), 127-70, S Žižek, The Parallax View (2006), G Agamben, The Time That Remains: A Commentary on the Letter to the Romans (P Dailey trans) (2005). For the recognition of the importance of Paul in contemporary Marxism, see R Boer, Criticism of Heaven: On Marxism and Theology (2009) 343-60. 
an avowed materialist. ${ }^{9}$ Badiou's main Marxist interlocutor, Slavoj Žižek, agrees, arguing that it is only the materialist who can give expression to the 'subversive kernel of Christianity'. ${ }^{10}$ But Badiou is fascinated by the power of Paul to rise above the constraints of his age and by the power of Paul's unreal fable (the 'fabulous') - that is, the resurrection of the crucified - to expose the paralyzing falsity of the past age in which he lived. In this sense, Badiou is completely at ease with a fable. It is the integral germination of an imaginary alternate construction that initiates the 'truth process' that extracts truth and its possibility from a communitarian stranglehold resisting its emergence. He calls this 'the fabulous forcing of the real'. ${ }^{11}$ Paul's militant commitment to this emergent truth arises as an antiphilosophical and antilegal declaration (Cf Rom 2:10, 1 Cor 1:18f, Gal 2:20-21) $)^{12}$ called forth by the totally new moment of the encounter with the resurrected crucified one. The emergent truth may retain, for a time, strategic negotiations of the philosophy and law of the previous dominant and dominating masters, as part of the process of release from the stranglehold. These negotiations utilise the word 'Christ/Messiah' of Jesus, make frequent references to the Hebrew scriptures, even uses Greek as the language of discourse, although under the powerful influence of the imaginary alternate construction are given a totally new amalgam. But the primary faithfulness to the declaration of the fabulous truth event is part of the very truth process that prevents it from being subsumed back into the prevailing order', through the contingent use of such language. ${ }^{13}$

Paul is prized as a subject. He is one who was able to rise, like the prophets that framed his upbringing, above the constraints of previous monolithic, immutable and self-justifying systems — whether that be Judaic law observance or Greek privileging of the logos. Badiou's prized texts are Romans 12:2, which he translates as 'Do not be conformed to the present century, but be transformed by the renewal of your thought ${ }^{14}$ and Galatians 3:28 — 'neither Jew nor Greek, slave nor free, male nor female'15 — for Badiou the fundamental affirmation about Truth and the condition of universality. ${ }^{16}$ The new, emerging universal lies beyond and must not be constrained by any particularism, whether that be the particularism

9 Badiou, above n 7, 2; A Badiou, Metapolitics (J Baker trans) (2005) 60, 68-77.

10 S Žižek, The Puppet and the Dwarf: The Perverse Core of Christianity (2003) 6.

11 Badiou, 5 Cf 56. For Badiou, the fable itself (resurrection of the crucified) is dispensable even though the subject's enunciation and its initiation of a universal truth process remain as testimony, precisely to that possibility amidst the otherwise despairing impossibility of truth or justice in and arising from a 'preconstituted historical aggregate' (6).

12 Badiou, above n 7, 9, 14, 41-2.

13 M Pound, Žižek: A (Very) Critical Introduction (2008) 80.

14 Badiou, above $\mathrm{n} 7,110$.

15 Ibid 9, 109. Cf Romans 10:12 (57).

16 Badiou, above n 7, 57, 109. See M de Kesel, 'Truth as Formal Catholicism — On Alain Badiou, Saint Paul: La fondation de l'universalisme' (2007) 1 International Journal of Žižek Studies 8. 
of identity politics (gays, disabled, feminist etc) or the particularism of law and wisdom posturing as a universal, especially as they respectively enforce and espouse a particular morality as universally binding. Paul's epistles themselves are prized over against other literary forms (including gospels and acts along with the texts of law and wisdom). The occasional, critical, nonsystematic form of the authentic letters is crucial to the 'forceful extraction of an essential core of thought'. ${ }^{17}$ The contingency of the letters - what Nils Dahl calls the 'problem' of the particularity of Paul's letters ${ }^{18}$ - is not for Badiou a problem at all. Their value can and must never become a frozen substitute for the central, dynamic, unfolding and fabulous resistance to the hegemonic dominance of institutions and systems in the present. Everything returns to and is inspired by the event that stands against both law and philosophy - the resurrection of the crucified one. The truth of this event enters into the process of emerging revelation through Paul's conviction and faithfulness to it. As Nick Hewlett observes, 'It is not possible to prove (in an empirical, positivist sense) that an event has taken place, as the truth process associated with the event only exists through the active commitment of those who declare its existence and importance'. ${ }^{19}$ This is why there is almost nothing of Jesus' life, sayings and work in Paul's letters - they simply do not matter; indeed, they cloud the revelation.

Truth is a process that gathers momentum, adherence and memory and is tied to a subject that constantly fights against conformity to some monolithic pretender. Badiou, like Slavoj Žižek (another Marxist rescuer of Paul), ${ }^{20}$ is critically concerned not merely with the ability of a subject to make a break with the past but with the subject's ability to resist and overcome the 'McDonaldsisation' of language and thought - the inability of thinking other than the status quo, the freezing over of any imaginative conception of an alternative. ${ }^{21}$ This notion of process is important because it will help to save Badiou's universalism from the very charge that threatens to undermine it, as in all Marxist systems: the displacement of one monolith by another. Badiou is careful to say, though, that it is not the removal of differences but rather the rendering of them as insignificant, that is critical to this universalism. He

17 Badiou, above n 7, 33. See R Boer, 'The Perpetual Allure of the Bible for Marxism' (2007) 15 Historical Materialism 62.

18 N Dahl, 'The Particularity of the Pauline Epistles as a Problem in the Ancient Church' in O Cullman (ed), Neotestamentica et Patristica (NovTs 6) (1962), 261-71.

19 N Hewlett, 'Engagement and transcendence: the militant philosophy of Alain Badiou' (2004) 12 Modern \& Contemporary France 343.

20 See S Žižek, The Fragile Absolute or, Why is the Christian Legacy worth fighting for? (2000).

21 See A Cadwallader, 'In Go(l)d we Trust: Literary and Economic Exchange in the Debate over Caesar's Coin (Mk 12:13-17)' (2007) 14 Biblical Interpretation 486, 486-507. 
has no wish to offer any solace to fascist tendencies. ${ }^{22}$

Although Badiou claims that his reading of Paul is independent, ${ }^{23}$ there is much in his portrayal and even in his very assertion of independence that reveals Badiou as a surrogate protestant individualist. ${ }^{24} \mathrm{He}$ admits that Paul is a 'cultural revolution on which we all depend' ${ }^{25}$ and there is regular reference to biblical scholars and their consensus. ${ }^{26}$ Badiou speaks of Paul's conversion and 'Damascus convocation' ${ }^{27}$ and ignores the current scholarly consensus that Paul's experience constituted a 'call' not a 'conversion'. 28 'Conversion' accents discontinuity, the very fracturing with the past that Badiou favours. 'Call' accents continuity, even though it is possible to see the prophetic nature of Paul's call as itself equally radical in its vision and practice of a break-through reconfiguration of the past inheritance. ${ }^{29}$ The danger is always that a mere transgression of the law will negate the possibility of a new society and social vision precisely because it draws its energy, its violence from that very law. ${ }^{30}$

Badiou also reiterates the traditional emphasis on the displacement of the way of the flesh for the way of the spirit, ${ }^{31}$ though, in Badiou's case, without sacrifice of a

22 References to contemporary and past French politics run through his work. Note especially his critique of Le Pens: Badiou, above n 7, 8-9, Cf 44.

23 What he calls a 'direct reading' of the text. He wants to avoid all obscurantism, frequently the bane of hermeneutics. See A S Miller, 'An Interview with Alain Badiou: 'Universal Truths and the Question of Religion" (2005) Journal of Philosophy and Scripture 3.

24 This in a curious way accompanies his 'formal Catholicism', understood as universality: see de Kesel, above n 16, 2.

25 Badiou, above $\mathrm{n} 7,15$.

26 He is, however, prepared to make significant contributions of his own, such as the reframing of translation equivalents for key technical terms - eg, pistis as conviction rather than 'faith' — so as to remove the mouldy layers of religiously constraining and distorting meanings: Badiou, above $\mathrm{n} 7,15$ Cf 41 .

27 Badiou, above n 7, 17, 20. In this, he uncritically adopts the Lukan Acts framing of Paul, even though he recognises Acts as 'the Hollywood version', harbouring a 'pro-Roman benevolence' (at 27, 30).

28 The seminal essay is that of Krister Stendahl, 'Call Rather than Conversion' in K Stendahl, Paul among Jews and Gentiles (1976) 7-23. See also J Munck, Paul and the Salvation of Mankind (1959). J D G Dunn, "A Light to the Gentiles', or 'The End of the Law'? The Significance of the Damascus Road Christophany for Paul' in L D Hurst and N T Wright (eds), The Glory of Christ in the New Testament (1987) 251-66. Some try to have it both ways: Cf F J Matera, Galatians (Sacra Pagina) (2007) 62-4.

29 Badiou may contest this given that, for him, the prophet in Judaism is the archetypal expositor of signs, which Paul set himself against. Badiou, above n 7, 41.

30 See C Packman, 'Towards a Violent Absolute: Some Reflections on Žižekian Theology and Violence' (2009) IJŽS 3, 3-5.

31 K Jackson, 'The Great Temptation of 'Religion': Why Badiou has been so important to Žižek' (2007) 1 IJŽS 11. 
materialist foundation. He rejects all law as the antipathy of truth and accents the radical newness of the idea and the bearer. ${ }^{32}$ Greek and Jew are constructed not as ethnic but as monolithic systems, almost ciphers, much like they became signs of Renaissance philosophy on the one hand and Catholic legalism on the other in Martin Luther's reformational rhetoric. ${ }^{33}$ The very prizing of letters ${ }^{34}$ is reminiscent of the preference for essays, one of the key instruments of the action of the reformation. The sheer privileging of Paul even over the Gospels, Badiou himself recognises is found in Luther. ${ }^{35}$ In this sense, there is, as Žižek has noted, ${ }^{36}$ a legacy of idealism in Badiou's work, that is, a trace of the metaphysical reification of the subject and the program/ vision. In the overarching accent on the radical newness of the event - its declaration and adherence to it (ALL, it should be noted, comprising the emergent truth) — the influence from and importance of the past are discounted. The problem here is that historical materiality, for all Badiou's commitment, is eviscerated if not evaporated. Consequently, Badiou, ironically, is inured to the influences that have facilitated his reading of Paul — what Biblical scholars today call 'the old perspective', ${ }^{37}$ even if Badiou's reading is leached of any metaphysic. Moreover, it induces, even requires, a minimization of both historical and literary influence, so that, for example, Badiou reads the 'I' refrain of Romans 7 ('the thing I hate I do') as biographical. ${ }^{38}$ There is no acquaintance with the ancient rhetorical form of prosopopoion - the adoption of a generic role, a 'speech-in-character' — that would see Paul adopting a generic character, which may include himself but is certainly designed to a self-identification among his addressees. ${ }^{39}$ Consequently, the universalism that Badiou extracts from his heroic subject, as new and vibrant and open as he may claim, can only be secured by an erasure not merely a denial ${ }^{40}$ of the influence of past particulars. Such an erasure, threatens the real - the truth he is eager to declare - far more than his overt denial, of the material reality of the resurrection of the crucified one. In this

32 Badiou, above n 7, 13-15.

33 See, eg, Luther's A Commentary on St Paul's Epistle to the Galatians (P S Watson trans) (1953), 129-31.

34 Badiou, above n 7, 31 .

35 Badiou, above n 7, 33. Interestingly, Roland Boer forges a link with Calvin: Boer, above n 17, 64.

36 S Žižek, On Belief(2001), 125; Žižek, above n 8, 56, 326.

37 See D Boyarin, A Radical Jew: Paul and the Politics of Identity (1994), 41-2.

38 Badiou, above $n$ 7, 79-81. Badiou in fact pits Paul against rhetoric which he sees as nothing but an arm of the very philosophy that has built one ideological expression of the masterly monolith from which Paul is extracting himself and others (at 27,36). This is where Badiou's subjective use of Paul staggers against the valid claims of history and exegesis (Cf at 2).

39 See S Stowers, A Rereading of Romans: Justice, Jews and Gentiles (1994), 264-72; see, by contrast, A Kotsko, 'Politics and Perversion: Situating Žižek's Paul' (2008) 9 Journal for Cultural and Religious Theory 51.

40 Badiou overtly denies any influence from past particulars, previous differences: Badiou, above n 7, 2 . 
he comes dangerously close to the obscurantist phenomena of capitalist imperialism he abhors.

\section{From Marxist universal to Jewish particular}

A radically alternate appreciation of Paul comes from the Jewish scholar of the New Testament, Mark Nanos. If, for Badiou, 'the production of equality and the casting off, in thought, of differences are the material signs of the universal', ${ }^{41}$ for Nanos the continuing Jewishness of Saint Saul ${ }^{42}$ is manifest as fundamental in his writings and even the Acts of the Apostles. Paul remained a Torah-observant Jew and was recognized as such by those around him. ${ }^{43}$ The offensive particularism of Paul's hereditary and personal commitment has of course been submerged beneath a 'universal' Gentile church that has rationalised its own historical accidence as a supercessionist sign of God's providence. Part of Nanos's project is the removal of the anti-Jewish bias from commentary on particular key texts of the Pauline corpus. ${ }^{44}$ But his overarching theme is Paul's construction of a major new narrative of Jewish negotiation of the Gentile world. The cipher of religious/philosophical typology is removed here as Nanos pushes Paul back into his heritage (claiming he never left it!) and the battles for that heritage that command so much of first century Jewish life.

For Nanos, Paul's remarkable but highly disputed achievement is to reconfigure the way in which Gentiles and Jews can relate in the worship of the one God and in the social interactions that flow from that monotheistic base. His addressees are equally Jewish and Gentile. Paul, according to Nanos, takes seriously the vision of the incoming of the Gentiles as part of Jewish election and hope. The critical issue is how that would happen. Nanos sees Paul as historically particularist in the extreme in that the fundamental confirmation of the incoming of the Gentiles does not lie in

$41 \quad$ Ibid 109.

42 See D H Akenson, Saint Saul: A Skeleton Key to the Historical Jesus (2002), who not only accents the Jewishness of both Paul (Saul) and Jesus (Yeshua) but who adopts such a maximalist position on the Jesus references in Paul's writings that far more than the crucifixion-resurrection is rendered critical to the apostle.

43 M Nanos, The Irony of Galatians: Paul's Letter in First Century Context (2002) 3.

44 See, eg, his assertion of a polytheistic calendar in Gal 4:10: ibid 267-268. See also his timely reminder that 'dogs' is a ubiquitous term of derision throughout the Mediterranean world: M Nanos, Paul's Reversal of Jews Calling Gentiles 'Dogs' (Phillipians 3:2): 1600 Years of an Ideological Tale Wagging an Exegetical Dog? (2008) <http://www.marknanos.com/Phil3DogsReverse-1-17-08.pdf> at 9 September 2011. I have explored the gendered elements of the use of 'dogs' as insult at length, arguing that gender, not ethnicity, is foundational to its use: see A Cadwallader, Beyond the Word of a Woman: Recovering the Bodies of the Syrophoenician Women (2008). 
Gentiles going through the ritual process of circumcision in order to be full members of the community of God worshippers. ${ }^{45}$ This, quite literally, would remove their identity and identification as Gentiles. In other words, any hope of the universal for Paul does not lie in the obliteration of, or indifference to, the distinctions between Jew and Gentile, but in full knowledge and recognition of them. Here universalism, catholicity, is constructed not through a revolutionary new humanity but by an equally revolutionary new conception of appreciation of the particular distinctions within humanity.

For this reading to gain traction and to be faithful to it, Nanos takes the historical and rhetorical context as critical both to Paul and to the interpretation of Paul. Both history and rhetoric inextricably shape Paul's discourse and cannot be ignored. One example will suffice. In Paul's letter to the Romans, the metaphor of grafting is taken into the argument of trying to explain the historical process of Gentile inclusion (Rom 11:17-24). Gentile commentators and translators through to the present day have taken the metaphor of grafting to read some branches are 'broken off' and replaced by others. ${ }^{46}$ This goes completely against the gardening techniques known in the ancient world. ${ }^{47}$ Rather, branches were incised but not severed and other branches were sutured into the gap. Hence, Nanos favours the translation 'dislocated' or 'sprained'. ${ }^{48}$ They are still identified as wild even though they are now part of the natural, even if grafted in 'against nature' (Rom 11:24). Nanos affirms that 'Paul maintains the proposition that those from the nations who respond to this good news of Christ remain members of the other nations thereafter, joining alongside of Israelites in the worship of the One God of all the nations'. ${ }^{49}$

Here one can see the obverse of Badiou's accent on universalism as a rupture from the particulars of the past. Rather, the particulars are regarded as absolutely critical to universalism precisely in their particularity. The crucial work of achievement of a universal that embraces the particular is a combination of continuity with the heritage of all parts with the dialogical imagination that produces a revolutionary

45 Nanos, above n 43, 6.

46 See, recently, de Kesel, above n 16, 17.

47 See Columella, De re rustica 5.9.16; Theophrastus, De causis plantarum 3.7.5-12; Theophrastus, De historia plantarum 2.7.12. For exposition see M Nanos, 'Broken Branches': A Pauline Metaphor Gone Awry? (Romans 11:11-24) (2008) <www.marknanos.com/BrokenBranches-8-1-08.pdf> at 9 September 2011; P E Esler, 'Ancient Oleiculture and Ethnic Differentiation: The Meaning of the Olive-Tree Image in Romans 11' (2003) 26 JSNT 103.

48 M Nanos, 'Romans 9-11 from a Jewish perspective on Christian-Jewish Relations', Paulus Magazine (Italy), 10 June 2009, 3. He recognizes that the language in Romans 11: 22-24 does indicate severance, but that this operates as an a fortiori argument for the sake of Gentile Christbelievers.

49 Ibid 272. 
new engagement. For biblical scholars, Nanos's work is a significant innovation on what is called 'the new perspective' on Paul.

\section{Finding the universal and particular in the Creator}

A revolutionary new engagement, I would like to suggest, can actually be achieved by a return to theology - Paul's theology or at least as informed by Paul. This in no way is to escape from the materialist commitments, upon which our Marxist brothers and sisters rightly insist, into some metaphysical flight from the world. And I hope that it will make possible a measure of dialogue between Badiou and Nanos - not a synthesis which would be anathema to both, for the one obscurantist and for the other a deficit.

I would like to suggest that for Paul the fundamental issue at stake in the Christ event has to do with what Badiou somewhat dismissively terms the Father. In theological terminology it is the problem of theodicy - the justification of God. This is not to do with the old chestnut of the problem of suffering and evil and its reconciliation with a powerful, caring God. Rather, it is the conundrum of trying to hold together God's justice and God's faithfulness in regard to creation. In reductionist terms, this seeks to resolve the fundamental tension between a holy God reacting against a creation that has defiled itself along with God's own intentions and a faithful God who has persevered in forbearance to seek out relationship with that creation. ${ }^{50}$

The key determinative image of God for Paul is God as Creator. For Paul, God as Creator cannot be untrue to God's own self. This requires that God remain as Creator. To be Creator requires creation, requires creatures. Creation is necessary if God is to be and is to remain Creator - in short, if God is to be God. This understanding of God dominates Romans from its opening (see Rom 1:19-25). God therefore must take responsibility for the continuing relationship with creation. God's justice and faithfulness are both determined by and subject to this basic affirmation.

Here is the contribution and part resolution to the fundamental issue of the universal and the particular raised thus far. Because God is Creator - not an immovable absolutist but a dynamic ongoing relational and relating subject, then God, for Paul, must be in relation, seeking relation. This does not require some anachronistic,

50 In recent Pauline scholarship, for the accent on the righteousness of God, see E Käsemann, Perspectives on Paul (1971); J Fitzmyer, Romans (1992); for the accent on the faithfulness of God, see B Byrne, Reckoning with Romans (1986), J D G Dunn, The Theology of Paul the Apostle (1998). Along with the dialogue with Badiou and Nanos, my approach owes some of its inspiration to R B Hays, Echoes of Scripture in the Letters of Paul (1989) and L E Keck, Paul and His Letters (2nd ed, 1988). 
static Trinitarian sense $\mathrm{e}^{51}$ but rather needs to be understood as a consequence of the fundamental characteristic of Creator. For Paul, any exposition of incarnation or resurrection must be predicated on the human-divine relationship. Either category as fundamental truth event (to fall back on Badiou's terminology) must be grounded in a dynamic process of creator-creature relationality.

Here, oddly enough, is not merely the theodicy that Paul is committed to establishing (that is, how God can be both faithful and just in the light of God's promise to the world through the historic accidence of Israel) but a justification of God that is predicated on the affirmation of God as Creator. If God as Creator requires an ongoing relationship with that which is created, so the theological reasoning of Paul unfolds with particular reference to the faithfulness of both God and Jesus (Creator and representative creature: see Rom 5), then here is the model to be imitated between creatures, whether that be ethnically-culturally based or even ecologically grounded.

This, for Paul, sacrifices neither truth nor difference. Jew and Greek remain Jew and Greek. Both are, of necessity, critical both to God and to one another, even when, in the necessary dialogical engagement, there are elements of the mediocre in the one and the militarist in the other. In this sense, Paul's theological agenda is not idealist but fundamentally processual and materialist, precisely because God as creator requires creation in ongoing dynamic relation if God's fundamental subjectivity is to be preserved. The quality of that subjectivity and relationality demands constant engagement with the truth of that relationship — what in jargonistic biblical discourse would be called justification and sanctification - but which is now predicated not on a final telos but on a constant engagement and generation of truth.

The qualification therefore that exists over all relationality is the 'not-finishedness' that Levinas recognizes for dialogue, that Badiou asserts for ontology and that Žižek perceives in materialist discourse. ${ }^{52}$ We must resile from sounding as if, in the 'not-finished', we have an inkling of what we do not know and confer a completed ontology to that which has yet to be. In this sense, multiplicity is the very fabric of existence even in the limitations of description. Thus, the difference between subjects, whether creator and creature or Jew and Greek, cannot and must not be eradicated even as it cannot be completely described - this preserves the difference or qualitative distinction of both God and creature. At the same time, attention to this distinction is what generates the truth process and the organic relational quality and unpredictability of subjectivity: 'The subject does not sustain the universal order of Being but is a product of the event'..$^{53}$

51 Rightly criticized by Badiou, above n 7, 59, Cf 42-4.

52 Compare Jackson, above n 31, 6.

53 Ibid 11. 
What I have done here is turn the event of the resurrection of the crucified one to its proper purpose: the justification of God as creator-in-relation-with-creation. In this sense, the resurrection event itself is a participation in and a restoration of the relationships of creation. A materialist view therefore asserts the fundamental unity of creation in all its diversity, just as the ecologists have been trying to get through to us. This is not an idealist conception that would remove being from material reality — as Badiou and others have rightly warned us against $\mathrm{t}^{54}$ — but rather the means to hold and to see unity and diversity really together as a political process not (merely) a religious or humanist doctrine. A theological view embraces this materialistic witness as the fundamental testimony to the being-in-relation of the creator God just as Paul asserted (Rom 1:19-20) and to which Paul tied the Christ-crucified-resurrected event. Reapplying Badiou's terms, creation is the prime fabulous event.

Hence, we can see, I trust, both the limitations and the possibilities of an engagement between Paul and the Universal Declaration of Human Rights. Paul, I suggest, is not just about the subject's ability to rise above or break through the differences in a particular historical epoch masquerading as a universal monolith, to a universalism which discounts difference in commitment to some larger Truth. Rather, he is about justifying a God who is Creator, a descriptor that, in Paul's terms, fundamentally predicates a relationship that is characterized materially and organically. The truth of the relationship is therefore something that must be worked at, constantly processed, constantly made in a relationship which is variegated and mutable, and, allowing a trace of Badiou's great concern, constantly constructed in the freedom of the respective subjects in dialogue. It can become neither a law nor a philosophy, and it cannot be used as an instrument of control nor an advancement of academicallyinsinuated superiority. It must remain organically in process as a declaration calling forth the ongoing dialogue between particulars, even as it constantly seeks and establishes the Truth and Truths in the process of initiative and response. And this, Paul suggests, is what characterizes the relationship between creatures of difference. In this sense, universality must be predicated on constant engagement with the particular, a constant making rather than an imposition or a competition.

\section{An inaugural conclusion ...}

In this chapter, I hope to have demonstrated in method as well as content how particulars must be included in any discussion of the universal. To do otherwise would be immediately to destroy any hope of the universal before we have begun. By bringing Marxist, Jewish and Christian voices into dialogue, albeit under my own

54 Ibid 5. 
(decidedly contingent) univocality, ${ }^{55}$ particular accents have all made a contribution to an understanding and a possibility of the viability of universality. Any truth that may be recognised and prized can only be recognised as an outcome of the necessarily dialogical, open and 'in-formation' engagement between those of significant and particular difference. Any talk of the universality of rights (for creation in general as much as for human creatures in particular) can only ever be a processual striving after the truth of those rights as an expression of relationship (itself in process of articulation). Accordingly, any articulation can only be understood as a Pauline-style 'letter', tenacious and inspirational in its faithfulness to the Truth which itself relies upon just that faithful commitment even as it recognises that it remains unfolding, a 'being-in-becoming'. For a bill of rights to have any claim on the 'evental' ${ }^{56}$ nature of Truth in this understanding, it must avoid any monolithic inscription. It must incorporate openness to as yet undiscovered aspects of Truth in relationship and cultivate the dialogue between particulars as the necessary lifeblood of its ongoing viability for, and expression in, acts of 'making right'.

55 Badiou celebrates being in a triangular exchange with a Catholic (Stanislas Breton) and a Protestant (Günther Bornkamm) in his portrayal of Paul and his ideas: Badiou, above n 7, 3. 56 Badiou's term: Ibid $14 \mathrm{ff}$. 